\title{
Cleome viscosa Linn (Capparaceae): A Review
}

\author{
Harpreet Singh*, Amrita Mishra and Arun Kumar Mishra \\ Department of Pharmaceutical Chemistry, Central Facility of Instrumentation, School of Pharmaceutical Sciences, IFTM University, Lodhipur-Rajpoot, \\ Moradabad-244001, India.
}

\begin{abstract}
Cleome viscosa Linn. (Capparaceae) called as "Hurhur" is an annual, sticky herb found in plains of India, Africa, and Pakistan etc as a common weed. Plant and its parts (leaves, seeds, roots etc.) are used traditionally to cure variety of diseases. Traditionally the plant possess anthelmintic, carminative, anticonvulsant, antidiarhhoeal, antimicrobial, wound healing properties. The review shows that various phytochemical compound were isolated from whole plant and its parts (seeds, leaves, roots etc.). The review reveals the collection of important pharmacological activites like antimicrobial, analgesic, antiemetic, antidiarrhoeal, hepatoprotective, antifibrotic, antitumor, anticonvulsant and psychopharmacological. It also made emphasis on its application in biodiesel formation. The review draws attention towards the traditional, phytochemical and pharmacological knowledge accessible on Cleome viscosa Linn. which would be beneficial for researchers to discover novel chemical entities.
\end{abstract}

Key words: Anticonvulsant, Biodiesel, Cleomiscosin, Cleome viscosa Linn., Phytochemical, Psychopharmacological.

\section{SUMMARY}

- A number of phytochemicals isolated from various parts (root, stem, leaf and seed) of Cleome viscosa Linn have been reported. Out of them, terpenes, flavonoids, phenol carboxylic acid are major category. The coumarin, cedrene, $\alpha$-amorphene, ethyl palmitate, coumarinolignoids (Cleomiscosin A and B), and Eriodictyol-5-rhamnoside as chief pharmacologically active principle.

- Cleome viscosa Linn has been explored in a wide range of pharmacological activities such as antimicrobial, antiemetic activity, antidiarrhoeal, hepatoprotective, antifibrotic, antitumor, anticonvulsant and miscellaneous activities. Its anti-convulsant potential has been reported as prominent activity.

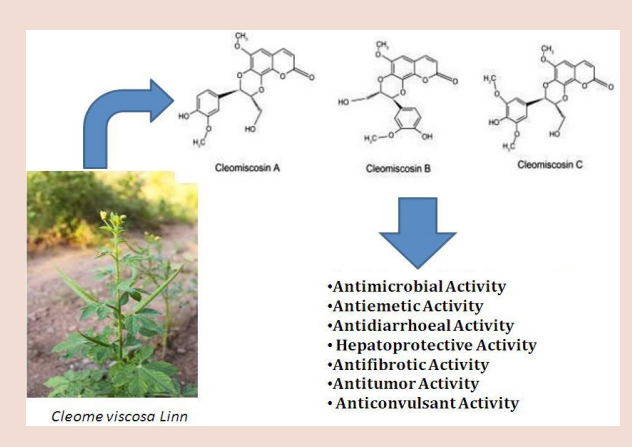

PICTORIAL ABSTRACT

Abbreviations used: MES: Maximal Electroshock, PTZ: Pentylenetetrazole, GC: Gas Chromatography, GC-MS: Gas Chromatography-Mass Spectroscopy.

Correspondence:

Mr. Harpreet Singh, Department of Pharmaceutical Chemistry, Central Facility of Instrumentation, School of Pharmaceutical Sciences, IFTM University, Lodhipur-Rajpoot Moradabad-244001, India.

Phone no: +91-8865934783

Email: singhharpreet747@gmail.com

DOI : 10.5530/pj.2015.6.1

\section{INTRODUCTION}

From old age, plants are used as crude material for drugs. In India, rich knowledge of medicinal importance of plants is available to the common people. About 3,500 plant species are useful as a source of crude drug in India. Medicinally important plants are about 2,500 in number. Some plant species are considered as a weed, but they are also medicinally important too. In various traditional and modern methods of therapy, plants products are used. In current era, the trend of using herbal medicine is in scope. New drugs are discovered by the invention of modern biotechnological and bioinformatics techniques. ${ }^{1}$ In current era, herbal medicines are used more often as human believe in natural therapies is increasing day by day. Novel clinically active drugs are discovered from the natural products isolated from higher plants and microorganisms. ${ }^{2}$ Cleome viscosa Linn. (wild or dog mustard), family (Capparaceae) is a sticky herb found as a common weed in plains of Pakistan, India, China, Ceylon, Africa etc and throughout the tropical regions of world annually. In traditional system of medicine leaves, seeds and roots of the plant are widely used as an anthelmintic, antiscorbutic, antiseptic, cardiac stimulant, carminative, febrifuge and sudorific, anticonvulsant, antidiarrhoeal, and are also used to treat skin diseases. ${ }^{3}$ It is called as 'Hurhur' in India. Traditionally Cleome viscosa Linn. plant is an antimalarial drug and useful in blood diseases, uterine complaints also. The pungent seeds and seed pods are used as a mustard substitute in curries. ${ }^{4}$

\section{Biological Description and Taxonomy}

Cleome viscosa Linn. is an annual, erect, 30-90 cm high plant. Stem of plant is grooved, densely clothed with glandular and simple hairs. Leaves of the plant are 3-5 foliolate. Lower leaves petioles are $2.5-5 \mathrm{~cm}$ long gradually becoming shorter upwards. The bracts are subsessile. Leaflets are elliptical-oblong or obovate, acute or obtuse. Petioles are short and hairy. Flowers are yellow in colour, axillary, growing out into a lax raceme. Pedicels are slender, terete and hairy. Sepals are $4.5 \mathrm{~cm}$ long oblong-lanceolate, glandular-pubescent outside. Petals are oblong-obovate, about $12 \mathrm{~mm}$ long, veined. Stamens are more than 20 in number. Capsules 5-6.3 by $0.4 \mathrm{~cm}$., erect, hairy, obliquely striate, compressed, tapering towards both ends, terminated by a style $3 \mathrm{~mm}$. long. Seeds are brown-black in colour when ripe, finely transversely striate, subglobose (Figure 1). ${ }^{5}$

$\begin{array}{ll}\text { Classification } & \\ \text { Kingdom: } & \text { Plantae } \\ \text { Subkingdom: } & \text { Tracheobionta } \\ \text { Superdivision: } & \text { Spermetophyta } \\ \text { Division: } & \text { Magnoliophyta } \\ \text { Class: } & \text { Magnoliopsida } \\ \text { Subclass: } & \text { Dilleniidae }\end{array}$




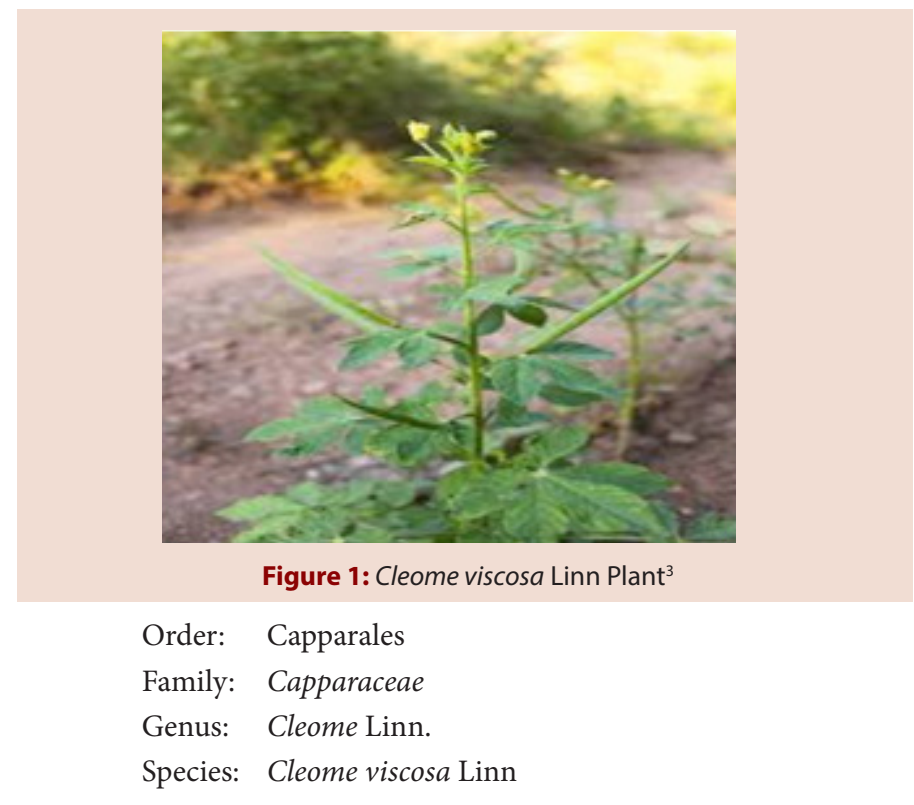

\section{Distribution}

Cleome viscosa Linn. occurs throughout the tropical regions of world. It occurs in India, USA, Nigeria, China, Ceylon, Pakistan, Africa. ${ }^{3}$

\section{Phytochemistry}

To isolate and characterize compounds, phytochemical work has been performed on various parts of the plant (root, stem, leaf and seed). Preliminary phytochemical screening of the extracts was performed and it was reported that terpenes, flavonoids, phenol carboxylic acid, polyphenols were present. ${ }^{2}$ It has been reported that monoterpenes hydrocarbons, sesquiterpenoids, oxygenated derivatives were isolated from leaves, seeds and root extracts. Compounds identified by Gas chromatography (GC), Gas chromatography/mass spectrometry (GC-MS), ${ }^{1}$ $\mathrm{H}$ NMR in leaves extract of Cleome viscosa Linn. were Heptane-4-one, a-pinene, camphene, dehydrosabenene, 6-Methylhept-5-ene-2-one, $\beta$-pinene, myrcene, $p$-cymene, limonene, E-ocimene, a-tepeniol, alloocimene, citronellic acid, coumarin, cedrene, $\alpha$-amorphene, ethyl palmitate. Oct-1-ene, $\alpha$-pinene, $\beta$-pinene, myrcene, $p$-cymene, E-ocimene, dehydrolinalool, undecan, allo-ocimene, limonene oxide, a-tepeniol, Decan-2-ol, citronellic acid, Deca-2,4-dien-1-al were identified in roots extract. In seeds extract, Oct-1-ene, Heptane-4-one, Heptane-2-one, Non-1-ene, a-pinene, dehydrosabenene, 6-Methylhept-5-ene-2-one, E-ocimene, myrcene, p-cymene, limonene, dehydrolinalool, undecan, limonene oxide, $\alpha$-tepeniol, benzoic acid, Deca-2,4-dien-1-al, Decan-2ol, Gerniol, Undec-10-e-1-al, coumarin were detected. ${ }^{6}$ Viscocic, viscosin (monomethoxy trihydroxyflavone) were identified in seeds. ${ }^{7}$ Eriodictyol5-rhamnoside (Novel glycoside) has been isolated from whole plant. ${ }^{8}$ Cleomiscosin A and B were detected in seeds extracts. ${ }^{9}$ Glu-cocapparin and glucocleomin (glucosinolates) ${ }^{10}$ and cleomaldeic acid ((3E, 7E, 11E) 20-oxocembra-3, 7, 11, 15-tetraen-19-oic acid) a macrocyclic diterpene have been separated from whole plant. ${ }^{11}$ Some of the phytoconstituenmts are presented in Table 1.

\section{Pharmacological Activity}

In view of it's traditional claim in literatures, researchers have focused on its pharmacological screening. Out of all the activities reported, some important activities are explained in this manuscript as:

\section{Antimicrobial Activity}

The antimicrobial study was performed on various extracts of Cleome viscosa Linn. seeds. Eight microbial species were used. Petroleum ether
Table 1: Important Phytoconstituents of Cleome viscosa Linn ${ }^{8-10}$

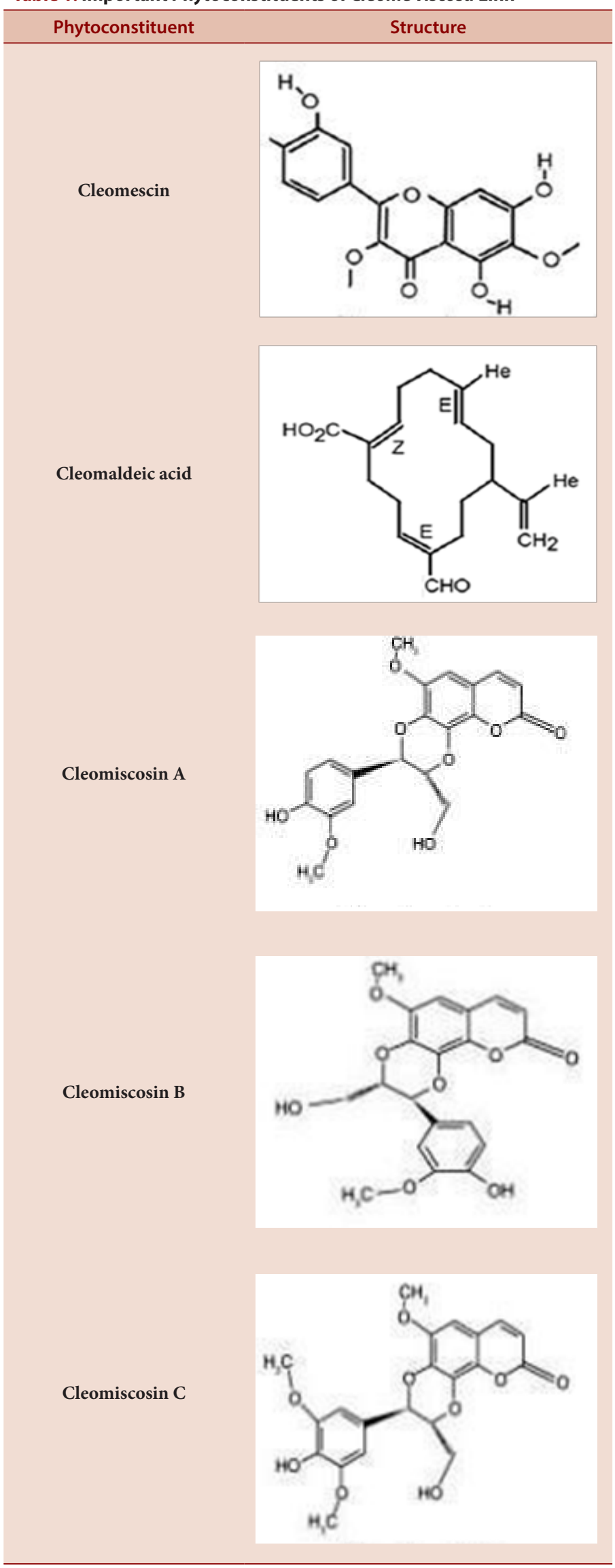


extract, chloroform extract, ethyl acetate extract, ethanol extract and aqueous extract of Cleome viscosa Linn. seeds were screened against these eight microbial species. Clinical samples of pus from ear ache patients were also used. The test materials have shown significant antimicrobial activity. The zones of inhibition were found to be between $10 \mathrm{~mm}$ to $17 \mathrm{~mm}$. The Minimum inhibitory concentration (MIC) values of extracts were also determined against microorganism which ranges from 0.1 to $0.45 .^{12}$

\section{Analgesic Activity}

A study was performed to evaluate the analgesic effect of Cleome viscosa Linn. in experimental animal models. The number of writhes were decreased at doses $(75 \mathrm{mg} / \mathrm{kg}$ body weight, $100 \mathrm{mg} / \mathrm{kg}$ body weight, $125 \mathrm{mg} / \mathrm{kg}$ body weight) of Cleome viscosa Linn. seeds fixed oil when compared to aspirin treatment and the control. Fixed oil in doses of $(75 \mathrm{mg} / \mathrm{kg}$ body weight, $100 \mathrm{mg} / \mathrm{kg}$ body weight, $125 \mathrm{mg} / \mathrm{kg}$ body weight) reduces the writhes number by $91.69 \%, 92.33 \%$ and $96.0 \%$, respectively. At a dose of (150 $\mathrm{mg} / \mathrm{kg}$ body weight) the mice group treated with aspirin had 11 writhes. But the control group had 62 writhes, thus the positive effect of aspirin was that it reduces the writhes by $82.42 \%$. The acetic acid induced writhing method is an effective method to evaluate peripherally active analgesics. $^{3}$

\section{Antiemetic Activity}

A study was performed to evaluate the antiemetic effect of Cleome viscosa Linn. fixed oil on young chicks. Fixed oil in doses of $(75 \mathrm{mg} / \mathrm{kg}$ body weight, $100 \mathrm{mg} / \mathrm{kg}$ body weight and $125 \mathrm{mg} / \mathrm{kg}$ body weight) reduces the retches number by $84.43 \%, 85.56 \%$ and $91.77 \%$, respectively. At a dose of ( $150 \mathrm{mg} / \mathrm{kg}$ body weight) the chicks group treated with chlorpromazine had 47 retches. But the control group had 68 retches, thus chlorpromazine reduced the retches by $30.56 \%$. Cleome viscosa Linn. seed oil inhibited emesis to a greater extent than chlorpromazine. On the basis of these results, it may be said that the fixed oil of Cleome viscosa Linn. has antiemetic potential and is comparable with chlorpromazine, which can relieve nausea. ${ }^{3}$

\section{Antidiarrhoeal Activity}

For evaluation of the effect of a Cleome viscosa Linn. methanolic extract (Family; Capparidaceae) for its anti-diarrheal potential against some of the models of diarrhoea in rats, "A study was performed". In castor-oilinduced diarrhoea and $\mathrm{PGE}_{2}$ induced enteropooling in rats inhibitory activity was observed due to extract. A significant reduction in gastrointestinal motility in the charcoal meal test in rats was also shown by the extract. From the results achieved it was cleared that Cleome viscosa Linn is an effective anti-diarrhoeal agent. ${ }^{13}$

\section{Hepatoprotective Activity}

In experimental animal models, hepatoprotective activity of Cleome viscosa Linn. ethanolic extract against carbon tetrachloride induced hepatotoxicity was evaluated. In "in vivo" and histopathological studies, the test material was found effective. The extract effectively shortenend the "thiopental" induced sleep in animal poisoned with carbon tetrachloride. Cleome viscosa Linn. ethanolic extract showed similar effect as "Silymarin" a standard hepatoprotective agent. From the result observed it was cleared that Cleome viscosa Linn. ethanolic extract is an effective hepatoprotective agent. ${ }^{14}$

\section{Antifibrotic Activity}

The study was performed to evaluate the antifibrotic activity of Cleome viscosa Linn. ethanolic extract. Carbon tetrachloride was used to induce liver fibrosis in rats. By observing the level of liver hydroxyproline, thiobarbituric acid and serum enzymes the extent of liver fibrosis was assessed. Hydroxyproline, thiobarbituric acid and serum enzymes levels were elevated and total platelet was decreased after carbon tetrachloride administration. Hydroxyproline level, thiobarbituric acid level and serum enzyme level was reduced after treatment with two different doses of Cleome viscosa Linn. ethanolic extract. By Cleome viscosa Linn. ethanolic extract liver weight was reduced that was increased after carbon tetrachloride administration that causes the deposition of collagen. From the result obtained it was clear that Cleome viscosa Linn. ethanolic extract is an effective antifibrotic drug. ${ }^{15}$

\section{Antitumor Activity}

A study was carried out to evaluate the anticancer effect of Cleome visco$s a$ Linn. in experimental animal models. After 24 hours of tumor inoculation the extract was administered at the doses of $200 \mathrm{mg} / \mathrm{kg}$, and 400 $\mathrm{mg} / \mathrm{kg}$ body weight per day for 14 days. The mice were sacrificed after giving the final dose and 18 hours fasting. The effect of Cleome viscosa Linn. methanolic extract on the growth of transplantable murine tumor and life period of Ehrlich ascites carcinoma-bearing hosts was studied in current study. A significant reduction in tumor volume, packed cell volume, and viable cell count was observed due to Cleome viscosa Linn. methanolic extract. It also causes enhancement in the life period of Ehrlich ascites carcinoma-tumor bearing mice. In extract-treated mice the hematological profile was converted to more or less normal levels. From the results obtained it was clear that Cleome viscosa Linn. methanolic extract causes significant antitumor effect in Ehrlich ascites carcinomabearing mice. ${ }^{16}$

\section{Anticonvulsant Activity}

A study was performed to evaluate the anticonvulsant activity of Cleome viscosa Linn. seeds extract by Maximal Electroshock induced seizures (MES) test and Pentylenetetrazole induced seizures (PTZ) test. Significant activity was shown by both ethanolic and aqueous seeds extract in MES and PTZ induced convulsions. ${ }^{17}$

\section{Psychopharmacological Activity}

For different psychopharmacological actions such as general behaviour, exploratory behaviour, muscle relaxant activity and phenobarbitone induced sleeping time and effects on normal body temperature in rats and mice, Cleome viscosa Linn. methanolic extract was evaluated. Reduction in spontaneous activity, decrease in exploratory behavioural pattern by the head dip and Y-maze test, reduction in the muscle relaxant by rota rod, 30 degrees inclined screen and traction tests and lowering of body temperature was observed after extract administration. Extract also causes significant enhancement in the phenobarbitone-induced sleeping time. At $200-400 \mathrm{mg} / \mathrm{kg}$ dose Cleome viscosa Linn. methanolic extract showed significant psychopharmacological effect. ${ }^{18,19}$

\section{Cleome viscosa Linn-Biodiesel Application}

By chemical reaction of the lipids (vegetable-oil, animal fat) with an alcohol, biodiesel "vegetable-oil or animal fat based fuel" consisting of alkyl (methyl, propyl, or ethyl) esters can be obtained. Biodiesel is a clean burning alternative fuel to diesel. It is produced from domestically grown renewable resources. In variety of biodiesel alkyl esters are present but not in alkanes and aromatic hydrocarbons of petroleum derived diesel. Cleome viscosa Linn. seeds oil was used to prepare biodiesel. The physiochemical properties were studied for blended portion of biodiesel. The physico-chemical properties assessed includes, specific gravity, density, viscosity, flash point, fire point, cloud point, pour point, smoke point, $\mathrm{pH}$, viscosity, carbon residue, saponification value, acid value, and iodine value. ${ }^{20}$

\section{Toxicity Studies}

It has been reported that Cleome viscosa Linn. is safe during acute toxicity studies in female swiss albino mice. ${ }^{17}$ 


\section{CONCLUSION}

Cleome viscose Linn. has been examined meticulously for its phytochemical and pharmacological activityies. From the aforementioned explanation, it is noticeable that Cleome viscosa Linn. has been used as an important curative agent for various ailments, as discussed in the review. The review cited the use of Cleome viscosa Linn. seeds oil in the biodiesel production also. Numerous compounds were isolated from plant which are accountable for its pharmacological activities.

\section{ACKNOWLEDGEMENT}

Authors are grateful to Dr. R. M. Dubey, Honourable Vice-Chancellor, IFTM University, Moradabad for continuous encouragement and providing necessary facility for literature review work.

\section{CONFLICT OF INTEREST}

The author declares no conflict of interest.

\section{REFERENCES}

1. Packialakshmi LN, Oviya K. Phytochemical analysis and HPLC screening of Cleome viscosa. Bio Med Res. 2014; 1(1): 1-8.

2. Brindha $P$, Niraimathi $K L$, Karunanithi M. Phytochemical and in vitro screening of aerial parts of Cleome viscosa Linn. Extracts (Capparidaceae). Int J Pharm Pharm. Sci. 2012; 4(1): 27-0.

3. Mohtasheem ul Hasan M, Salman A, Munnawar S, lqbal A. Analgesic and Antiemetic activity of Cleome viscosa L. Pak J Bot. 2011; 43(1): 119-2.

4. Panduraju T, Parvathi B, Rammohan M, Reddy CS. Wound healing properties of Cleome viscosa Linn. Hygeia J D Med. 2011; 3(1): 41-5.

5. Kirtikar AR, Basu BD. Indian Medicinal Plants. $2^{\text {nd }}$ ed. Dehradoon: India; 2005.

6. Gabriel O, Peter W, Stephen O. Chemical investigation of volatile constituents of Cleome viscosa from Nigeria. Bull Chem Soc Ethop. 2005; 19(1): 139-3.
7. Gupta RK, Dutt S. Chemical examination of seeds of Cleome icosandra. J Indian Chem Soc. 1938; 15(1): 532-3.

8. Srivastava SK, Srivastava SD. A new glycoflavanone from Cleome viscosa whole plant. Curr Sci. 1979; 48(1): 430-1.

9. Chattopadhyay SK, Kumar S, Tripathi S, Gupta AK. High-performance liquid chromatographic method for identification and quantification of two isomeric coumarinolignoids-cleomiscosin A and cleomiscosin B- in extracts of Cleome viscosa. Biomed Chrom. 2007; 21(11): 1214-20.

10. Songsak T, Lockwood GB. Glucosinolates of seven medicinal plants from Thailand. Fitoterapia 2002; 73(3): 209-6.

11. Rehman JC. Isolation of a new macrocyclic diterpene, cleomaldeic acid from Cleome viscosa. Phytochemistry 1990; 29(2): 666-7.

12. Wake RR, Patil NA, Khadabadi SS. In Vitro Antimicrobial activity of extracts of seeds of Cleome viscosa linn. Int J Pharma Sci and Res. 2011; 2(8): 2232-6.

13. Devi BP, Boominathan R, Mandal SC. Evaluation of anti-diarrheal activity of Cleome viscosa L. extracts in rats. Phytomed. 2002; 9(8): 739-2.

14. Gupta NK, Dixit VD. Evaluation of hepato-protective activity of Cleome viscosa Linn. extract. Ind J Pharm. 2011; 41(1): 36-40.

15. Kumar SV, Christina AJM, Geetharani PV, Nilini G, Chidambaranathan N. Antifibrotic effect of Cleome viscosa Linn. on Carbon tetrachloride $\left(\mathrm{CCl}_{4}\right)$ induced liver fibrosis. Der Pharm Chem. 2009; 1(2): 92-6.

16. Venugopal Y, Ravindernath A, Kalpana G, Prabhakar RV. Antitumor activity of Cleome viscosa against ehrlich ascites Carcinoma (EAC) in swiss albino mice. Int J Phyto Phar Res. 2012; 2(2): 51-5.

17. Mishra A, Mishra AK, Jain SK. Anticonvulsant activity of Cleome viscosa seeds extracts in swiss albino mice. Int J Pharm and Pharma Sci. 2010; 2(1): 177-1.

18. Devi BP, Boominathan R, Mandal SC. Studies on Psychopharmacological effects of Cleome viscosa Linn. extracts in rats and mice. Phytother Res. 2004 18(2): 169-2.

19. Ariharan VN, Meena Devi VN, Gopukumar ST, Nagendra Prasad P. PhysicoChemical analysis of Cleome viscosa L. oil: A Potential source for Biodiesel. Rasayan J Chem. 2014; 7(2): 129-2.

20. Ariharan VN, Meena Devi VN, Gopu Kumar ST, Nagendra Prasad P. Physicochemical properties of Bio-diesel obtained from Callophyllum innophyllum oil. Res J Pharm Bio and Chem Sci. 2014; 5(1): 64-1.

\section{ABOUT AUTHORS}

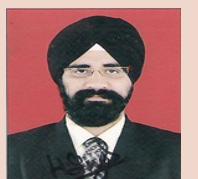

Mr. Harpreet Singh: Obtained his M. Pharm degree in Pharmaceutical Chemistry in 2012 from U P Technical University, Lucknow. He is currently working on the post of Assistant Professor in School of Pharmaceutical Sciences, IFTM University, Moradabad. He has to his credit 8 national and 5 internation research paper. He works in the area of synthetic medicinal chemistry, Phytochemistry and structure elucidation.

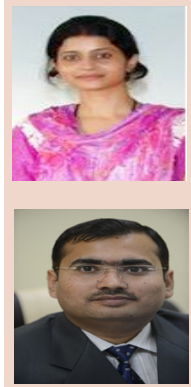

Dr. Amrita Mishra: Ph.D from Birla Institute of Technology, Mesra, Ranchi is working as Assistant Professor at School of Pharmaceutical Sciences, IFTM University, Moradabad. She works in the area of Herbal drug standardization, Phytochemistry and Pharmacognosy. She has vast experience of teaching, writting projects and research papers.

Dr. Arun K Mishra: Recipient of a fellowship from All India Council of Technical Education (AICTE) Govt. of India for M. Pharm. He is also recipient of Shipi Devi Memorial award from IFTM administration for best performance in P.G. Course. Currently, he is working as Assistant Professor in School of Pharmaceutical Sciences, IFTM University, Moradabad. He has, to his credit 38 research papers in International and International journals and 19 poster presentations in various National and International conferences. Presentlly he is supervising $4 \mathrm{Ph} . \mathrm{D}$ research scholars. 